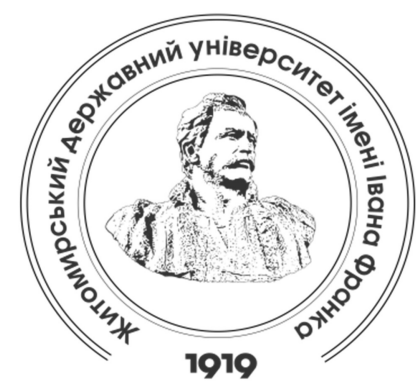

Zhytomyr Ivan Franko State University Journal. Philosophical Sciences. Vol. 2(88)

Вісник Житомирського державного університету імені Івана Франка. Фікософські науки. Вип. 2(88)

ISSN: $2663-7650$

UDC246.6.001.32(045)

DOI 10.35433/Philosophical Sciences.2(88).2020.50-58

\title{
CYBERRELIGION IN THE PERSPECTIVE OF POSTMODERN TRENDS: RELIGIOUS AND CULTURAL VIEW
}

\section{S. Melnychuk ${ }^{*}$}

The article presents some concepts of modern religious studies on cyberreligion as a postmodern phenomenon. The advent of modern technology and, in particular, computermediated communication has an important impact on the religious life of modern society. This scientific research is devoted to specific examples of the relationship between religious movements and organizations and scientific achievements and above all to the Internet space. These examples are illustrated by the author in the perspective of the diversity of typologies of religions, both traditional and modern religious movements. The emphasis placed by the author of the article is devoted to theoretical and methodological issues in the perspective of the concept of cyberreligion, respectively, the Internet space and Internet communications. Foreign approaches to the study of cyberreligion, the influence of the Internet on the formation of religiosity in the social space of the postmodern era are analyzed.

It is shown that the development of computer technology is associated with major changes in various areas of mass consciousness. Information, political, sexual and other revolutions of recent decades have liberated the minds of a huge number of people, expanded the boundaries of freedom of expression. Postmodern culture strengthened the position of relativism, made the mass notion of the relativity of the boundary between reality and illusion. The study of cyberreligion as a phenomenon of today has many benefits for understanding not only religious innovations, but also the general laws of the nature of religion, its origin and development.

It is investigated that the main objective condition for the emergence of cyberreligion was the existence of a special sphere of human activity - the sphere of computer technology, which has become vital for modern people. We have pointed out that a person who comes into contact with this branch of life is aware of the high degree of its significance and content - it is a huge complex world, which contains new great opportunities and great prospects.

In this regard, today the question of the relationship between cyberspace and religion is becoming a matter of special discourse and requires further consideration and scientific prediction. There are a huge number of different religions on the Internet, and they are quite different. Attempts to explain and classify this phenomenon in modern religious studies are caused by the diversity and inconsistency of cyber-religious formations.

Key words: cyberreligion, globalization, cyberspace, cybertechnologies, religious discourse.

\footnotetext{
${ }^{*}$ Candidate of Philosopchical Sciences, Associate Professor

(National University of Water and Environmental Engineering, Rivne, Ukraine)

m.s.melnuchyk@nuwm.edu.ua

ORCID: 0000-0002-4299-968X
} 


\section{КІБЕРРЕАІГІЯ В РАКУРСІ ТЕНДЕНЦІЙ ПОСТМОДЕРНУ: РЕАІГІЄЗНАВЧО-КУАЬТУРОАОГІЧНИЙ ПОГАЯД}

\section{M. С. Мельничук}

У статті представлені деякі кониепиї сучасних релігієзнавчих студій щодо кіберрелігії як явища постмодерну. Поява сучасних технологій $i$, зокрема, комп'ютерноопосередкованого спілкування здійснюе важливий вплив на релігійне життя сучасного суспільства. Наукова розвідка присвячена конкретним прикладам співвідношення релігійних рухів $і$ організаиій та наукових досягнень $i$, в першу чергу, до мережі Інтернет простору. Ці приклади ілюструються автором в ракурсі різномаїття типологій релігій, як традиційних так і новітніх релігійних рухів. Акценти, котрі ставляться автором статті присвячені теоретичним та методологічним питанням в ракурсі поняття кіберрелігіі відповідно інтернет простору та інтернет комунікаиій. Аналізуються зарубіжні підходи до дослідження кіберрелігіi, вплив мережі інтернет на формування релігійності в соиіальному просторі епохи постмодерну.

Доведено, шо розвиток комп'ютерних технологій пов'язаний з великими зрушеннями в різних областях масової свідомості. Інформаиійні, політичні, сексуальні та інші революиї останніх десятиліть розкріпачили свідомість величезної кількості людей, розширили межі свободи самовираження. Культура постмодерну зміинила позиціi релятивізму, зробила масовим надбанням уявлення про відносність межі між реальністю й ілюзією. Вивчення кіберрелігіі як явища съогодення несе в собі багато користі для розуміння не тільки релігійних новаиій, а й загальних законів природи релігї̈, виникнення ї̈ та розвитку.

Досліджено, шо визначальною об'єктивною умовою виникнення кіберреліzіi стало існування особливої сфрери людської діяльності - сфери комп'ютерних технологій, котра стала для людей сучасності життево необхідною. Зазначено, шо людина, яка вступає в контакт з иією галуззю буття, усвідомлюе високу ступінь ї̈ значимості $і$ змістовності ие величезний складноорганізований світ, який містить в собі нові великі можливості та неабиякі перспективи.

У зв'язку з иим сьогодні питання про взаємозв'язок кіберпростору та релігії стає проблемою особливого дискурсу, яка потребує свого подальшого розгляду та наукового прогнозування. В інтернеті презентуеться величезна кількість релігій, $i$ вони досить несхожі. Спроби пояснити та класифікувати ие явище в сучасних релігієзнавчих науках спричинені різноманітністю та непослідовністю кіберрелігійних утворенъ.

Ключові слова: кіберрелігія, глобалізаиія, кіберпростір, кібертехнологї, релігійний
дискурс.

Introduction of the issue. With the advent of computers, the possibilities of creating fictional worlds, endowed with the maximum degree of plausibility, have increased many times over. Creative human imagination, having adopted cybertechnology, with particular conviction, represented in the horizon of existence, which is now often referred to as "virtual reality". Globalization is combined with privatization: modern man, especially the urban dweller, to a much lesser extent than before, needs systematic collective cultic communication. Religious life becomes a private affair, a personal choice within the most comfortable possibilities. Cyber technologies open up new opportunities for the privatization of religious life. Cyber technologies and the Internet provide a high level of communication and form new, networked communities. "Cyberia" is the seventh continent, filled in its religious dimension not only by hermit individualists, but also by wellorganized groups with intense religious communication. This is reflected in the lens of our scientific interests. An important problem for us is the nature of interest in cyberreligion as a phenomenon in the perspective of postmodern reality. Scientific interest in 
the problem of cybercommunications in the spiritual culture of today was reflected in the works of $\mathrm{B}$. Brascher, K. Helland, A. Karaflodzhi, P. McVell, A. Bonnet, J. Potter and many other theologians, philosophers and sociologists.

The aim of the article is show and analyze the contours of cyberreligion. which are endowed with the basis of mentality, in which computer technology acquires the status of superiority, saturated with the qualities of sacred objects and attributes of divine beings. It is important for us to emphasize that in the coordinate system of this mentality, computer virtual reality acts as a higher reality, a supervaluable otherness, which is outside of everyday existence and dominating it. In our scientific research, we point out that this type of mentality, together with the corresponding actions, attitudes and institutions, forms cyberreligion as a separate religious formation.

Results and discussion. At the end of the last century in the perspective of religious studies as a branch of humanities there was a stagnation primarily of a theoretical and methodological nature. The religious field was studied, measured and evaluated through the prism of the dominant paradigm of secularization. Approaches developed over the years to measure the social manifestations of religion began to be a kind of "industry cliché", which significantly limited the idea of the real state of the institution of religion and did not allow a wide range of experts to accept and sometimes reveal the emergence of new religious types. It is no coincidence that in 1985, the famous British researcher of religion James Beckford compared the religious studies of that time with "an airplane that drifts in flight on one wing" [1:56]. $\mathrm{He}$ expressed genuine concern that the field of religious studies was moving to the periphery and that recourse to the study of religion at national and international congresses was becoming increasingly exotic. Arguing that the general interest in the problems of religion and religious discipline in general is declining. However, much has changed over the last quarter of a century. The last decade of the last century and the beginning of the XXI century became a significant challenge in the field of religion research, when the religious factor began to play a significant role in international political events and social processes. This, in turn, gave rise to new sociological reflections with fundamentally different theoretical and methodological tools.

Typology and search for definitions of religion is an important problem of religious studies, which in the context of cyberspace acquires a specific quality. The typology of the religious discourse of cyberreligions, according to Anastasia Karaflodzhka, helps to study techno-religious formations, allows to track the emergence of new and development of existing cyberreligions, indicates the criteria for finding new cyberreligious movements and the degree of their relationship with cyberspace technologies. And in addition - reveals the features of cyberreligions in their various forms [2]. In the article "Religious Discourse and Cyberspace" Anastasia Karaflodzhka offers three different typologies of cyberspace religions, which are presented to us in their evolutionary development.

The first typology refers to the religious discourse of cyberspace and includes its types such as objective, confessional, personal and subjective. To the objective type of religious discourse Karaflodzhka includes those areas of cyberspace that focus on the scientific study and description of religious traditions. These are the web pages of universities, institutes, scientific journals that consider religion from a religious and theological standpoint. The denominational type of cyberspace religious discourse marks 
the official web pages of various traditional and new religious and spiritual beliefs. They contain information on doctrines, religious practices; in addition, some controversial issues arising on religious grounds can be identified and addressed here. Such areas of the Internet, being official, mostly represent the positions of leaders of certain religious movements. The personal type includes pages and sites created by individuals who want to share their religious views, ideas and experiences, communicate with other believers, discuss the doctrines of different religions. These pages reflect the individual perception of a religion. According to Karaflodzhka, they are "like a window into the inner world of the individual" [2: 211].An important role here is played by the design of web pages, which indicates either the personal skill of the creator, or his material well-being and can influence the perception of religious ideas. The subjective type, according to Karaflodzhka, is generated by a critique of religion and the religious situation and includes certain groups of believers who are in opposition to any tradition. As an example of this type of religious discourse in cyberspace, she cites the official website of the Taliban (www.afgan-

web.com/politics/taliban.html).

Anastasia Karaflodzhka's second typology only slightly clarifies the first, and, according to the author himself, this clarification is due to the development and diversity of cyberspace discourse. The objective type here came to be called scientific, denoting the opinion of scholars (not always implies objectivity), the personal became part of the subjective, and the confessional was singled out as the third type. In this form, the objective type includes the discourse of universities, research organizations, online books, publications of individual scientists, as well as scientific forums, research groups and online courses. Denominational, in addition to the web pages of church organizations, means the above-mentioned Internet phenomena such as virtual churches, rituals, pilgrimages, prayers, sermons. In addition, these include electronic bulletin boards, mailing lists, newsgroups on religious topics. The subjective type includes religious groups, religious forums, publications, cyberrituals and cybermemorials that do not belong to the established church institutions and express the religious positions of individuals. Cyber-rituals and worship on the Internet are usually performed in three-dimensional virtual software environments, the presence of which in real time is associated with the creation of "avatars", an animated interactive object that represents the user in virtual reality. Anastasia Karaflodzha distinguishes two types of cyber-rituals: 1) rituals of institutionalized religions, which are mainly descriptive and textual, 2) rituals that can be defined as pagan or new age [2].

Karaflodzhka's third typology characterizes not so much the religious discourse of cyberspace as the very forms of religion on the Internet, including the two main categories. The main criteria of this typology are the attitude of religion to cyberspace, its perception and understanding. According to Karaflodzhka, cyberspace can be seen either as a means or as a "new world where events can take place" [2: 184]. Due to this difference in the understanding of cyberspace, two types of religions are derived: "religion outside cyberspace" and "religion in cyberspace". "Religion outside cyberspace" is based on the perception of the World Wide Web as a means. Rather, it is not a religion, but information presented "by any religion, church, person or organization that also exists in reality" [2: 185]. 
Cyberspace here is a type of communication and nothing more. An example of this type is any religious website with informational functions. As for "religion in cyberspace", which Caraflodzka also calls the term "cyberreligion", it is a religious entity created and existing exclusively in cyberspace and using the Internet as a kind of habitat.

Cyberia abounds in churches and houses of worship, as well as synagogues, meditation halls, memorials (similar to cemeteries) and other religious objects, which recreates the religious environment in cyberspace, in which a person feels the effect of presence and complicity. Numerous sites offer interactive forms of interaction. The visitor can not only read the text, watch the video, listen to music or sermon. Anyone can take part in the voting or poll, enter into online communication with other visitors, speak on the forum, leave an entry in the guest book, pray, order a service for "health" or "rest", light a virtual candle and otherwise be active, realizing their religious or other needs. All the variety of forms of religion in cyberspace can be divided into two main types. The first type is a denomination cyber resource (denominational resource). It is represented by content that represents in cyberspace religions that have emerged outside of virtual reality and that use digital technology as a means of improving the effectiveness of religious activities. The existence of cyberreligion in the form of computergenerated resources (computer sites, forums, newsletters, disks, etc.) is already fully described in modern religious studies. However, the cyber resource of denominations is not the only type of cyberreligion. In essence, this type is marginal to traditional religions and secondary to cyberreligion as a neoplasm. In the form of a confessional resource, cyberreligion has no signs of self-sufficient religious formation - it has no independent ideological and psychological platform, no specific rituals, no institutions [1]. Of course, cyber technologies, in comparison with traditional means of communication, open qualitatively new opportunities for religious communities, but in fact confessional cyber resources are substantively and functionally related to other ways of representing religious life, such as print or television media. In fact, the cyber resource of denominations is a virtual projection of the existing in the "reality" of religious life of denominations.This is convincing not only the content of religious cyberresources, but also expressed in official documents or private statements attitude to computer technology of the denominations. It is pragmatic in nature and focuses primarily on the use of these technologies for information support. Followers of Islam see the Internet primarily as an information resource. In Catholic and Orthodox circles, digital technologies and the Internet are also associated with hopes of increasing the effectiveness of missionary activity.Representatives of these currents of Christianity suggest that some types of religious activity (eg, preaching, visiting holy places) may have an analogue in cyberspace, if necessary, but categorically against the sacraments (say, confession) on the Internet. Buddhists and Jews, guided by their doctrines, do not place much emphasis on the missionary capabilities of computer technology, assigning them the role of information and integrating factor. Characteristically, the rules of traditional religious practice are transferred to human use of computer technology. Yes, a Jew cannot use the Internet on Saturdays and sacred holidays. Judging by the content of the sites of many new religious movements, their creators adhere to a proper understanding of the purpose of cyber technology. Some of these movements use cyberspace as a powerful 
mobilization resource.A typical example is Falun Gong. The websites of this banned international religious community in China are persistently drawing attention to the tragic fate of $\mathrm{Li}$ Hongzhi's followers in China, calling for united and active protests against the repressive policies of the Chinese government. It should be noted that the possibilities of cyberspace are used as a resource not only by traditional or new institutionalized religions. Representatives of occultism, magic and other similar forms of religious life intensively saturate cyberspace with their books, horoscopes, advertisements (as an example we can mention the Satanic Church of Antoine Sandor Lavey) [3: 83]

Cyberreligions, in turn, are also divided into two categories. The first includes some unprecedented phenomena, the creators of which bring a "new understanding of postmodern religiosity" [2]. Examples of such formations are Cosmosophy (a doctrine that, synthesizing ancient and modern views of science, studies the principles of the universe, as well as the subjectobject relationship of man and space), Digitalism (a movement that originated in the early 80's. XX century. Due to the spread of computer technology in the field of art), Technosophy (one of the Sofia disciplines, as subjects of which are "wisdom" and the spiritual side of technology. Technosophy studies the relationship of technology with metaphysical, theological, mystical plans of existence) and other. The second type of cyberreligion is called the "new cyberreligious movement" (NCRM), which "can be a form of response, reaction, call to action or even rebellion against religions, entrenched in the world outside the Internet" [2: 186]. As an example, Karaflodzka cites cyber organizations such as Parthenite, which exists entirely in cyberspace, and Falun Gong, which is "somewhere between" in and "outside" [2: 186].

In his article, Christopher Helland also attempts to organize knowledge about the religious phenomena of cyberspace, highlighting such criteria as the type of communication inherent in the religiously conditioned formation of the World Wide Web and the associated degree of human participation in cyberspace. $\mathrm{He}$ distinguishes between "religion-online" and "online religion". According to Helland, "religion-online" is information about religion [4: 296]. Here, the Internet is used to represent a particular system of religious beliefs and, again, is used as a means. This type is associated with the type of communication "one - most", it is a form of one-way communication, when the user does not have the opportunity to respond to the information offered to him and only passively perceives it.

Religious spaces on the Internet, characterized as "religion-online", are usually created by those religious organizations that are strictly hierarchical in structure. They have complete control over their subordinate software environments, eliminating the possibility of connecting and linking to questionable web pages. Christopher Helland writes that these websites do not have interactive features such as chat, uncontrolled bulletin boards and contact areas where people can send their prayers or requests, because all this interferes with organizational control. Such a software environment is methodically built, carefully protected and constantly monitored. This identifies a possible type of complicity, and thus the organization retains full control over the cyber environment. Such a model is used to a greater extent by official religious organizations, but also by various "newer religious movements or groups that practice a more Congregational form of government" [4]. Although this 
type undoubtedly has its advantages for both users and religious organizations, according to Helland, it also poses some danger to those who use it, as it often cannot compete with other types of religions on the Web - "online religion". The fact is that most people who travel on the World Wide Web want to use it as a form of multilateral communication. In turn, "online religion", providing web users with an interactive environment, offers them the following form of communication "majority - majority", when a person can interact with the religious organization itself, as well as with other users.This ensures a high level of human participation and creates a favorable environment for the formation of virtual communities, or communitas. In addition, such a model contains not only the informational, intellectual aspect of religion, but also its actional side, and involves communication and rituals, prayers, pilgrimages, and so on. In this case, cyberspace should be understood as a place, an environment, and not just as a means of communication. However, according to Helland, the shortcomings of "religiononline" can be minimized in two ways.

The first involves the availability of the site in several languages, and the second involves the creation of a "cyber world", which is achieved by connecting a large number of web pages within the site. In this case, the official web page can create an imitation of several sites that are connected by hyperlinks, although in reality it is a connection of pages designed by the same creators and subordinate to them. A religious organization does not lose control of the information or software environment by linking pages within the site. According to Helland, this "allows for active participation, while most online religions allow only one passive form of communication" [4]. As for "online religion", it is mostly inherent in unofficial religious sites, which, representing personal religious views, according to Helland, are presented on the World Wide Web more widely than institutional positions. According to Christopher Helland, "online religion" exists in cyberspace in three areas. First, it can manifest itself in official religious websites that have software environments where users can discuss their beliefs, discuss, share religious feelings and experiences, pray together, and so on. Helland argues that within the Catholic tradition, examples of such sites are www.catholic.org and www.partenia.com. Second, "online religion" is particularly characteristic of the unofficial religious sites mentioned above. This also includes the so-called "techno-language groups" [4: 298]. In these cases, divination, rituals, etc. are offered in parallel with online prayers and discussions. Examples are www.thepaganweb.com, which has its own electronic bulletin board, chat rooms, research groups, online seminars and online rituals. "Online religion" is also associated with those doctrinal systems that see the Internet as a spiritual reality - "from New Age movements to occult or magical groups, Wiccanism or pagan revival, technopaganism and transhumanism.

Transhumanism - a philosophical movement, arguing that man can evolve to infinity, believes that technology will play a huge role in this process, and strongly supports technological progress. Transhumanists seek to further with the help of nanotechnology, biotechnology, information technology, developments in the field of artificial intelligence, loading consciousness into computer memory and cryonics to eliminate aging and death, increase mental and physical capabilities. The third area where online religion occurs is commercial endeavors and websites created specifically for religious interaction that go beyond the usual framework of church hierarchy and 
structure.Free religious discussions are possible here, and in reality these sites often do not belong to any particular religious denomination. Examples of this form of online religion are Christopher Helland's beliefnet.com and spiritweb.com. He points out that there are also commercial sites based on Wiccanism(www.witchvox.com), occult or magical beliefs (www.techoetic.com/noosphere/resourc es/Magic/). Commercial websites also include several free chat rooms from organizations such as Yahoo. In summary, we should point out some similarities between the third typology of Karaflodzhi and the typology of Helland. Both authors distinguish between "the Internet as a means" and "the Internet as a place". It should be noted that Helland's classification highlights the importance of such factors as the interactive participation of people in cyberspace, the form of communication and the level of control used by websites over their subordinate Internet environments. In this respect, the typology proposed by Patrick Maxwell is more correlated with Karaflodzhka's third typology.Being identical in appearance to Helland's classification, it actually contains the essence of "religion in cyberspace" and "religion outside cyberspace" with the only difference that Karaflodzhka sees in "religion outside cyberspace" some superstructure of real religion, while Maxwellpoints to a kind of theoretically subordinate nature of the private manifestations of cyberreligiosity of Internet religion in general.

"We used the term "religion online" as a more general term to describe various religious formations and manifestations in cyberspace in general, and used the term "online religion" only in situations where people try to practice their religions in cyberspace, especially in the case of online worship, sending rituals online, online prayer meetings and online memorial services" [5: 276], - explains the author. At the same time, it should be noted that Maxwell does not set himself the task of systematization, but only states the terms and their meanings, adopted and used among his colleagues.

\section{Conclusions and research} perspectives. Modernization "liberated" the individual, and the postmodern Christian world of today bears little resemblance to the former, where the place and role of religion were clearly marked and therefore unambiguously identified. Under the pressure of changing modernity, institutionalized religions seek to be active players in the "market" of production and distribution of worldviews and socially significant norms and attitudes of consciousness. Thus, we can draw conclusions about some pre-XXI century typologies of religion in cyberspace. I must say that the authors themselves insist on the need for further development and refinement of these classifications, which, in particular, due to the dynamism of religion, and the Internet, and technologies that are in constant transformation and development.In addition, it is necessary to study religion in cyberspace from the standpoint of comparativism, and for this it is important to compare religious phenomena of the Internet not only in different religious traditions but also in different countries and cultures, because this problem is not a reflection of one socio-religious environment multicultural heritage. The question of the influence of virtual reality on the psyche of the individual and how it can relate to religious experience and religious worldview require separate consideration. In any case, we have to keep in mind that cyberspace is a constantly transformative environment, and, therefore, religion will operate here in more and more new and modern forms. 


\section{LITERATURE}

1. Brasher B. Give me that online religion. San Francisco: Jossey-Bass, 2001. 203 p.

2. Karaflodzhka A. E-religion. A Critical Appraisal of Religious Discourse on the World Wide Web. London: Equinox, 2006. 224 p

3. Melnychuk M. Antichristian and satanic motives in the formation of the ideological core of "metallic" music: religious and art analysis. Bulletin of Zhytomyr State University named after Ivan Franko. Philosophical Sciences 2016. Issue №1 (82). P. 81-85.

4. Helland Christopher. Surfing for Salvation. Journal Religion Volume 32, 2002. Issue 4. P.293-302.

5. Maxwell Patrick. Virtrual Religion in Context Alpha Books, 2002. 380 p.

\section{REFERENCES (TRANSLATED \& TRANSLITERATED)}

1. Brasher, B. (2001). Give me that online religion. San Francisco: JosseyBass (in English).

2. Karaflodzhka, A. (2006). Ereligion. A Critical Appraisal of Religious Discourse on the World Wide Web. London: Equinox (in English).

3. Melnychuk, M.

(2016). Antichristian and satanic motives in the formation of the ideological core of "metallic" music: religious and art analysis. Bulletin of Zhytomyr State University named after Ivan Franko. Philosophical Sciences , 1 (82), 81-85 (in English).

4. Helland, C. (2002). Surfing for Salvation. Journal Religion, 32, (4), 293302 (in English).

5. Maxwell, P. (2002). Virtrual Religion in Context. Alpha Books (in English).

Receive: August 21, 2020 Accepted: September 25, 2020 